Andrzej Pawlik, dr hab. prof. UJK

Uniwersytet Jana Kochanowskiego w Kielcach

Kielce, Poland

ORCID: https://orcid.org/0000-0003-2319-6707

Paweł Dziekański, PhD

Department of Economics and Finance

Jan Kochanowski University in Kielce

ORCID: https://orcid.org/0000-0003-4065-0043

Magdalena Wrońska

Department of Economics and Finance

Jan Kochanowski University in Kielce

Kielce, Poland

ORCID: https://orcid.org/0000-0001-8368-154X

Urszula Karpińska

Cooperative Bank in Kielce, Poland

ORCID: https://orcid.org/0000-0002-4032-8823

DOI: https://doi.org/10.30525/978-9934-26-018-6-6

\title{
ASSESSMENT OF THE INFRASTRUCTURAL POTENTIAL IN RELATION TO THE DEVELOPMENT PROCESS OF THE TERRITORIAL UNIT
}

Local self-government meets the collective needs of residents. Carries out socio-economic tasks (own or commissioned). The basis for the implementation of public tasks (in the field of technical and social infrastructure, public order and safety, spatial and ecological order (Act 1990)) is own property (developed infrastructure), including financial resources. Infrastructure plays a special role in shaping the settlement and social and economic development of the region. Its shortcomings determine the low standard of living, difficulties in management and attractiveness for investors (Salomon 2006). According to M. Ratajczak (1999), infrastructure is essential for development processes to take place at all. W. Kamiński (1995) mentions demographic, natural, capital and other factors among the 
spatial conditions of multifunctional development, next to the level of technical and social infrastructure development.

The aim of the article is to assess the diversity of municipal infrastructure using a synthetic measure and the interdependence between development and the level of infrastructure. To build synthetic measures, the Technique for Order Preference by Similarity to an Ideal Solution (TOPSIS) method was used. The empirical data was collected in spatial terms for 484 rural communes of the Eastern Poland region (voivodships: Lubelskie, Podlaskie, Podkarpackie, Świętokrzyskie and Warmińsko-Mazurskie). The choice of variables was conditioned by the availability of data in the Local Data Bank of the Central Statistical Office for 2009-2018.

\section{Influence of infrastructure on the development of communes.} The infrastructure performs service functions (satisfying reported needs for services), transfer (movement of goods and people, transfer of energy and information), integration (connecting areas in a micro and macroscale), localization (factor of the production system location), activation (activates local and regional development)) (Kuciński 2009). Infrastructure investments have a significant impact on economic development and are therefore one of the most important tools of development policy. Undoubtedly, the use of infrastructure as a factor in the development of space is related to the conduct of local investment policy. Its aim is to increase the attractiveness and credibility of the commune as a place of residence and job creation, which determines the chances of further development. Due to the high costs of infrastructural investments, not every commune can fully finance the expenses from its own income (Kołodziejczyk 2012).

Methods research. The following stages were distinguished in the process of building a synthetic feature:

I. Selection of variables describing the examined objects.

II. Determining the direction of variable preferences in relation to the phenomenon under consideration (definition of stimulants and destimulants).

II. Performing zero unitarisation (Walesiak 2005). 
IV. Calculating the synthetic measure according to the TOPSIS method for individual objects (Jahanshahloo, Lotfi, Izadikhah, 2006; Dziekański, Pawlik, Wrońska, Karpinska, 2020).

$\mathrm{V}$. In the last stage, the studied area was divided into 4 quartile groups. Descriptive statistics measures and correlation were assessed (Dziekański, Prus 2020; Pawlik, Dziekański 2020).

Results. Table 1 shows the groups of rural communes in eastern Poland according to the level of infrastructure. The classification of municipalities was based on the percentiles $(2,4,6,8)$, which were threshold values for the subsequent groups. The TOPSIS synthetic measure for infrastructure ranged from 0.22 (the weakest unit) to 0.45 (the best unit) in 2009 and from 0.28 to 0.50 in 2018 . The development measure ranged from 0,20 to 0.31 in 2009 and 0.23 to 0.36 in 2018 . The correlation between the indicated areas is 0.832 . This may indicate a similar range of differentiation of individuals in both analyzed areas and their similar reaction to changes taking place in the economy.

Table 1

Groups of measures of synthetic potential of infrastructure of rural communes in eastern Poland in 2009 and 2018

\begin{tabular}{|c|c|c|c|c|c|c|c|c|c|c|}
\hline & \multicolumn{10}{|c|}{ Typological groups of infrastructure measure } \\
\hline & \multicolumn{5}{|c|}{2009} & \multicolumn{5}{|c|}{2018} \\
\hline & I & II & III & IV & $\mathbf{V}$ & I & II & III & IV & $\mathbf{V}$ \\
\hline 1 & 2 & 3 & 4 & 5 & 6 & 7 & 8 & 9 & 10 & 11 \\
\hline $\begin{array}{l}\text { Value of the } \\
\text { TOPSIS } \\
\text { synthetic } \\
\text { infrastructure } \\
\text { measure }\end{array}$ & 0,45 & 0,36 & 0,33 & 0,30 & 0,22 & 0,50 & 0,42 & 0,38 & 0,35 & 0,28 \\
\hline $\begin{array}{l}\text { Number of } \\
\text { communes }\end{array}$ & 100 & 109 & 110 & 79 & 86 & 93 & 95 & 88 & 121 & 87 \\
\hline $\begin{array}{l}\text { Value of } \\
\text { TOPSIS } \\
\text { synthetic } \\
\text { measure of } \\
\text { development }\end{array}$ & 0,31 & 0,26 & 0,24 & 0,22 & 0,20 & 0,36 & 0,31 & 0,28 & 0,26 & 0,23 \\
\hline
\end{tabular}


Table 1 (continued)

\begin{tabular}{|l|c|c|c|c|c|c|c|c|c|c|c|c|}
\hline \multicolumn{1}{|c|}{1} & 2 & 3 & 4 & 5 & 6 & 7 & 8 & 9 & 10 & 11 \\
\hline \multicolumn{7}{|c|}{ Determinants of the demographic and economic situation } \\
\hline $\begin{array}{l}\text { Population } \\
\text { per km } 2\end{array}$ & 90 & 56 & 45 & 42 & 45 & 103 & 59 & 48 & 37 & 40 \\
\hline $\begin{array}{l}\text { balance of } \\
\text { migration per } \\
1,000 \text { people }\end{array}$ & 2,6 & $-0,64$ & $-2,46$ & $-2,87$ & $-2,83$ & 2,36 & $-1,71$ & $-1,94$ & $-4,60$ & $-4,18$ \\
\hline $\begin{array}{l}\text { The } \\
\text { unemployed } \\
\text { registered in } \\
\text { communes } \\
\text { per 1,000 } \\
\text { inhabitants }\end{array}$ & 63 & 66 & 61 & 66 & 64 & 37 & 37 & 42 & 39 & 40 \\
\hline $\begin{array}{l}\text { People } \\
\text { working in } \\
\text { communes } \\
\text { per 1,000 } \\
\text { inhabitants }\end{array}$ & 97 & 83 & 62 & 61 & 61 & 113 & 91 & 80 & 71 & 66 \\
\hline $\begin{array}{l}\text { Entrepreneurs } \\
\text { hip rate } \\
\text { (Entities } \\
\text { entered into } \\
\text { the REGON } \\
\text { register per } \\
\begin{array}{l}1000 \\
\text { population) }\end{array}\end{array}$ & 53 & 51 & 45 & 44 & 45 & 69 & 64 & 62 & 55 & 55 \\
\hline $\begin{array}{l}\text { Natural } \\
\text { persons } \\
\text { running a } \\
\text { business per } \\
\begin{array}{l}1000 \\
\text { population }\end{array}\end{array}$ & 43 & 40 & 35 & 34 & 35 & 56 & 50 & 48 & 42 & 43 \\
\hline $\begin{array}{l}\text { Population } \\
\text { per library }\end{array}$ & 2826 & 2607 & 2543 & 2697 & 2154 & 3078 & 2877 & 2587 & 2597 & 2624 \\
\hline $\begin{array}{l}\text { Population } \\
\text { per 1 } \\
\text { pharmacy }\end{array}$ & 5914 & 4211 & 2921 & 2532 & 2829 & 5327 & 3735 & 2988 & 2383 & 2289 \\
\hline
\end{tabular}


Table 1 (continued)

\begin{tabular}{|l|c|c|c|c|c|c|c|c|c|c|}
\hline \multicolumn{1}{|c|}{1} & 2 & 3 & 4 & 5 & 6 & 7 & 8 & 9 & 10 & 11 \\
\hline $\begin{array}{l}\text { \% of the } \\
\text { population } \\
\text { using the } \\
\text { sewage } \\
\text { network }\end{array}$ & 42,5 & 21,7 & 13,3 & 14,7 & 8,8 & 68,5 & 42,4 & 30,4 & 19,1 & 13,3 \\
\hline $\begin{array}{l}\text { \% of the } \\
\text { population } \\
\text { using the } \\
\text { water supply } \\
\text { network }\end{array}$ & 83,1 & 80,1 & 79,2 & 64,4 & 40,1 & 89,2 & 84,9 & 88,7 & 83,8 & 54,0 \\
\hline $\begin{array}{l}\% \text { of the } \\
\text { population } \\
\text { using the gas } \\
\text { network }\end{array}$ & 46,7 & 16,3 & 6,0 & 6,6 & 7,4 & 50,9 & 23,4 & 8,9 & 3,3 & 8,7 \\
\hline $\begin{array}{l}\text { Housing stock } \\
\text { per 1,000 } \\
\text { inhabitants }\end{array}$ & 294,4 & 310,6 & 306,7 & 308,5 & 298,0 & 307,5 & 338,8 & 335,5 & 337,3 & 326,9 \\
\hline
\end{tabular}

Source: own study based on the BDL CSO data

The value of the synthetic infrastructure measure is higher than the development measure. It can be noticed that the communes of group 1 used the best development opportunities with the best infrastructural potential. In both analyzed areas, the value of the synthetic measure in group I is higher in 2018 than in 2009 ( 0.45 and 0.31 ).

The group of communes with the best situation (I) in terms of infrastructure was created by 93 communes in 2018 (100 in 2009), which accounted for 93/484 (100/484) respectively of all rural communes of Eastern Poland voivodeships. In the case of the weakest communes (group V), they accounted for 87/484 in 2018 (86/484 in 2009), respectively.

Multifunctionality of rural areas contributes to their development. The use of the rent of location in relation to urban areas (local development centers, core and periphery theory) creates opportunities for their faster development. The decrease in the number of the unemployed in all groups, the increase in the number of the employed, the increase in the number of entities entered in the REGON register 
and natural persons conducting business activity should be assessed positively. This may indicate that communes depart from a typically agricultural character.

Infrastructure is of great importance, primarily economic processes depend on it. It is an investment proposal and an offer of conditions necessary for running a business. The development of economic activity stimulates the development of infrastructure.

The analysis of the condition of the infrastructure of rural communes in eastern Poland shows that despite a significant increase in this respect, their condition is insufficient. Improving the equipment of the analyzed area with elements of infrastructure may have a positive impact on the growth of development and own incomes of communes, because these areas will become more attractive to potential investors.

The obtained results of the analyzes indicate a positive correlation between the measure of development and infrastructure. They also indicate that a higher level of infrastructure is associated with a higher socio-economic development. Local authorities should first of all take care to improve the economic potential, which will increase the attractiveness of the area and attract new entrepreneurs, create new jobs and improve the quality of life of the inhabitants. This should also contribute to the improvement of the income structure, strengthening of financial independence, and improvement of infrastructure.

\section{References:}

1. Dziekanski P., Pawlik A., Wrońska M., Karpińska U., 2020, Demographic Potential as the Basis for Spatial Differentiation of the Financial Situation Communes of Eastern Poland in 2009-2018, European Research Studies Journal Volume XXIII Special Issue 2.

2. Dziekański P., Prus P., 2020, Financial Diversity and the Development Process: Case study of Rural Communes of Eastern Poland in 2009-2018, Sustainability, 12.

3. Jahanshahloo G. R., Lotfi F. H., Izadikhah M., 2006, An Algorithmic Method to Extend TOPSIS for Decision-Making Problems with Interval Data, Applied Mathematics and Computation, 2 (175). 
4. Kamiński W., 1995, Variants of multifunctional rural development - spatial conditions, ZN AR im. H. Kołlątaj in Krakow, No. 295, issue 43, Krakow.

5. Kołodziejczyk D., 2012, The spatial diversity of water supply and sewer systems in Polish rural areas in the 1995-2010 period, Studia Regionalne KPZK PAN, nr 36.

6. Kuciński K., 2009, Economic geography, Wyd. Oficyna a Wolters Kluwer Business, Kraków.

7. Pawlik A., Dziekański P., 2020, Attractiveness of cities and communes of the Świętokrzyskie Voivodeship, Jan Kochanowski University, Kielce.

8. Pawlik A., Dziekański P., 2020, Socio-economic image of communes in the Świętokrzyskie Voivodeship, Jan Kochanowski University, Kielce.

9. Ratajczak M., 1999, Infrastructure in a market economy, Poznań 1999.

10. Salamon J., 2016, The impact of technical infrastructure on the development of the social environment of rural areas, Infrastructure and Ecology of Rural Areas, No. 2/1, PAN, Kraków

11. Branch.Act of March 8, 1990 on the commune self-government; Journal of Laws 1990 No.16, item 95 as amended.

12. Walesiak M., 2005, The problems of selection and weighting of variables in the problem of classification, Scientific Papers of the University of Economics in Wrocław, Taxonomy 12. 